\title{
Anglophile Journal
}

Vol. 1, No. 1, October 2020

https://www.attractivejournal.com/index.php/anglophile/

\section{The Effect of Collaborative Strategic Reading toward Students Reading Skill}

\author{
Ahmad Khoirul Anwar* \\ Universitas Hasyim Asy'ari, Indonesia \\ achmedanwar97@gmail.com*
}

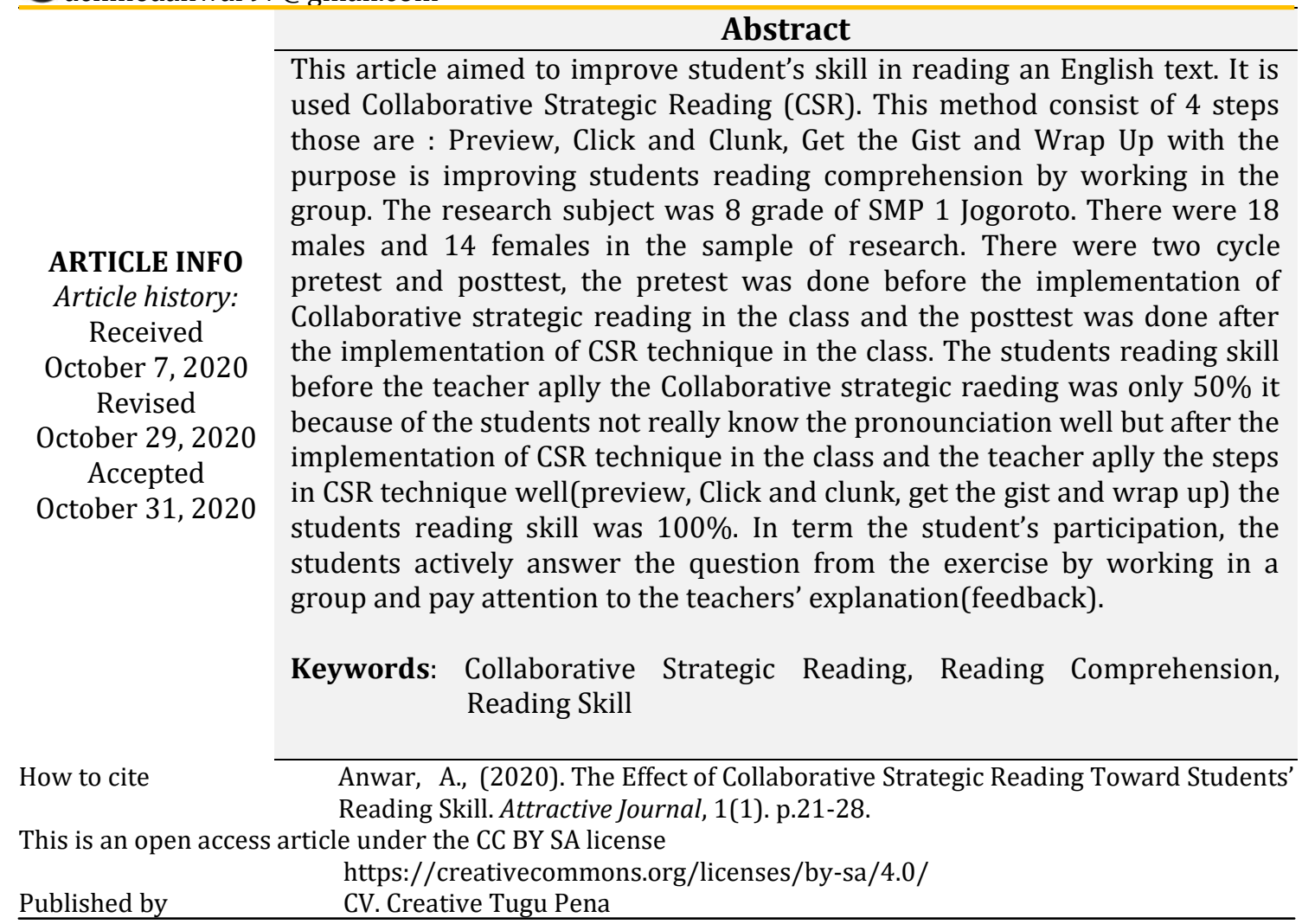

\section{INTRODUCTION}

In our life we need to communicate and connect with other people, because as human we have sociability that can not be erase from human, so language is important as a bridge between human. English is the international language every people around the world should understand about English. In Indonesia, English language plays an important role because the students in elementary school untill college students should learn about English (Suhono, \& Sari, 2017; Suhono, 2016; Haikal, H. 2018). It means that Minister of Education in indonesia want the generation of indonesia smart and ready to face the globalization. Unfortunately students in Indonesia not really understand about English, they feel difficult to learn because English language is really different from Indonesian Language: the pronounciation, the meaning etc (Sari, \& Suhono, 2017; Sari, Y. A., Utama, F., \& Yawisah, U. 2019; Hasyim, U. A. A., \& Suhono, S. 2017).

According to Hoetomo, (2005) skilled is capable in completing tasks, capable and deft. Skills are for completing assignments or required skills Speaking, Reading, Listening, and Writing are the skills that the students should be master in learning English Language but in this study the author choose Reading as skill that can make the students better to study about English (Saori, 2020). It is because the students not really know how to read in 
English text and feel difficult when interpret the English text. Based on an interview with the English teacher in SMP 1 Jogoroto in Jombang, Est Java. It is found that many students still have problems in reading. When the teacher asked the students to read the English text, they seemed to be less motivated and some other students are found lack of vocabulary, with the result that these situations make them difficult to understand what they are reading. The other problem from the students is fluency. Many students are not fluent in reading.

To make the students reading skill increase the Author use Collaborative Strategic Reading (CSR) strategy. Colaborative Strategic Reading is a strategy which purpose is improving students reading comprehension by working in group. Its strategies include previewing the text, click and clunk, getting the gist and wrapping up. CSR is originally designed by Klingner and Vaughn in 1996 that combines modified reciprocal teaching and cooperative learning. CSR strategy consist of 4 steps that the students apply before, during, and after reading in small group, in one group there are 5 students. The steps in the strategy: Preview(before reading), Click and Clunk (during reading), Get the Gist (during reading) and Wrap Up (after reading).

Elkaumy (2004) in Abidin and Riswanto (2012) explains the concept of CSR as the following: The concept of this strategy is engaging students to work in small cooperative groups (3-5) and apply four reading strategies: Preview, Click \& Clunk, Get the Gist and Wrap Up. Preview allows students to generate interest and activate background knowledge in order to predict what they would learn (Ross, 2020; Jannah, 2020). Click \& Clunk are self- monitoring strategy which controls their understanding about words, concepts and ideas that they understand or do not understand or need to know more about (Sembiring, 2020; Purnawan, 2019 ). Get the Gist. Students identify the main ideas from reading to confirm their understanding of the information. Wrap Up provides students with an opportunity to apply metacognitive strategies (plan, monitor and evaluate) for further extend comprehension.

In addition, Collaborative Strategic Reading is a strategy that make the students working together in small group, Each group consist of 5 students. All group would apply the steps in Collaborative strategic reading those are Preview, Click and Clunk, Get the Gist and Wrap up (Alqarni, 2015; Wu, J. Y., \& Peng, Y. C. 2017). Preview: the students predict about the English text and make the students interest about the topic. Further is described by Bremer, (2002) that the preview is a strategy for Activate student knowledge before reading. Click and Clunk: the students in each group try to find difficult word in the English text (Vaughn, 2011). Click and Clunk According to Boardman et al (2011) is a strategy that Teach students to monitor their understanding during reading and Look at the preceding sentence context, when there are words that are considered difficult Understood. Get the gist: the students try to find the main Idea in each paragraph by discussion in each group. According to Vaughn et. Al. In Standish, (2005) "Get the gist Also Known as a way to find the main idea and practiced when Read the text Wrap up: the teachers invites the students to evaluates the English text and the students try to find the conclusion from the text. Khonamri (2015) argues that wrap up is a strategy that Teach learners to generate questions and ideas for Review the main idea in the text he has read. By applying Collaborative strategic reading as reading strategy, the students are hoped to have improvement in reading skill.

\section{METHOD}

The researcher used Quasi Experimental design which is including of Pre-test and Post-test. The teacher carry out the Pre-test before apllying the Collaborative Strategic Reading strategy to the students. It is done because the teacher want to know the students reading ability before the implementation the CSR technique. And after the teacher apply the CSR strategy there the post-test was given to the students it is done because the 
teacher want to know the effectiveness of CSR technique toward students reading ability. the population in this study is all the students of SMP 1 Jogoroto especially at 8 grade in academic year 2019/2020. The sample of this research is class 8 I. Population is a generalization region consisting of objects or subjects that have certain qualities and characteristics set by the researchers To study and then with draw the conclusion (Sugiyono, 2010)

Instruments are tools used to collect data. According to Arikunto, (2019). To collect the data teacher need the instruments. It is made the teacher easier to know that the Collaborative strategic reading effective or not toward students reading skill. In this study there are 4 those are: Reading test consist of Pretest and Posttest, Observation, Interview, and Quesionare.

The reading test ability (pretest and posttest) is made by the reasearcher and directly corrected by the lecturer and also the English teacher in SMPN 1 Jogoroto. It is done to make the reading test valid in order the reading test is suitable for the students ability. there are many types of validity in this study it called Expert validation. The topic that were used in this study is from the students book, before making the reading test the teacher of SMP 1 Jogoroto order the researcher to continue the chapter in English book, the topic is "what are you doing". To know the students reading ability the researcher were made a reading test or Pre-test it was done before the implementation of CSR technique.

To find out the hypothesis is successful, which says there are significant differences before and after the application of the CSR technique and the effectiveness of CSR technique toward students reading skill, the writer employed a t-test. Hatch and Lazaraton (as cited in Tamah, 2000) argue that it is important to check the normality of the distribution when t-test is used. Therefore, the pretest as well as the post-test scores were checked for their normal distribution and equal variances. When normal distribution and equal variances were not met, nonparametric tests would be employed.

\section{RESULT AND DISCUSSON}

\section{The Students' Reading Skill before the Implementation of CSR Technique}

Table 1. Frequency distribution of pretest score in English reading skills

\begin{tabular}{cc}
\hline Frequency & Interval \\
\hline 2 & 50 \\
2 & 68,75 \\
9 & 62,5 \\
19 & 56,25 \\
\hline
\end{tabular}

From the table above, in this pre-test there are 2 students got 50 scores, 2 students got 68,75 scores, 9 students got 62,5 scores and there are 19 students got 56,25 scores. It means that there is no students reach the KKM value. It is proved that the students reading ability is really low, they were not motivated and not really interest when reading english text. 


\section{The Students' Reading Skill after the Implementation f CSR Technique}

Table 2. Table Frequency Distribution of Posttest

\begin{tabular}{cl}
\hline Frequency & Interval \\
\hline 3 & 62,5 \\
4 & 68,75 \\
4 & 75 \\
5 & 81,25 \\
7 & 87,5 \\
9 & 93,75
\end{tabular}

From the table above it can conclude that there was improvement before the implementation of CSR technique and after the CSR applied to the students. There were 3 students got $62,5,4$ students got $68,75,4$ students got 75,5 students got $81,25,7$ students got 87,5 and there were 9 students got the highes scores or 93,75 .

\section{The Effectiveness of Collaborative Strategic Reading Toward Students' Reading Skill at $8 I$ Grade of SMP 1 Jombang.}

Table 3. Scores Posttest and Pretest English Reading

\begin{tabular}{lccc}
\hline $\begin{array}{l}\text { Scores } \\
\text { effectiveness }\end{array}$ & Mean & Gain scores & Weight of \\
\hline $\begin{array}{l}\text { Posttest } \\
\text { Pretest }\end{array}$ & 51,58 & 22,98 & $8.8 \%$ \\
\hline
\end{tabular}

The statistical hypothesis in this study was tested using T test, with significance level (a) $5 \%$. Calculation of the T test was completed with SPSS for windows 13.0 program. Hypothesis criteria are accepted if the price is calculated smaller than $t$ table at a significance level of 5\%, Ho is accepted and Ha rejected and. Conversely, if the price of $t$ is greater than Ttable at $5 \%$ significance level then Ho is rejected and Ha is accepted.

\section{The Students Reading Skill Before the Implementation of CSR Technique At VIII I Grade of SMPN 1 Jombang.}

Before the teacher apply the collaborative strategic reading to the students or it called pre-test. the researcher need to know the students capability in reading English text, so the teacher would prepare all of the stuff that needed in this research. The teacher obtained the pretest results it was apprehensive about the scores of the students. From 32 students at 8I grade in SMP 1 Jogoroto no one students reach the KKM of the English Lesson. When the teacher asked the students how they like Study English, most the students did not interast to learn English they felt so less motivation when read the English text. There are many problem that the researcher should solved those are: the students did not understand the meaning of the English text, the teacher did not really good in teaching English reading, the students did not know how to read the English text because it really different from reading in indonesia. In Summary, the students reading skill before the implementation of CSR technique is really low it can be seen from the scores above. The pre-test mean scores is 58,6.

The Students Reading Skill after the Implementation of CSR Technique at 8 I in SMP 1 Jogoroto 
After the teacher apply the collaborative strategic reading to the students who used to be enthusiastic about learning English are now very different, they respond well when the teacher explains about English lessons, they are also more fluent in reading English texts. This is because the CSR model requires students to learn cooperatively so that they are more willing to read and appreciate their opinions aloud.

In line with the statement above, (Finandar, 2012) explained that CSR techniques consist of two parts. That part is strategy and learning Cooperative. Fortunately students can be invited to work together to apply the collaborative strategic reading. They really helps this research so that their posttest scores are better than their pretest scores. It can be seen from their mean scores of pretest and posttest. The pretest scores of the students were 58,6 it really different after the implementation of CSR technique the posttest scores were 81,58 that means the CSR technique is very effective on the students' ability to read English text.

\section{The Effectiveness of CSR Technique Toward Students' Reading Ability}

Based on the Ttest calculation, it was concluded that there was significant differences in students reading skill in learning achievement English reading skill at grade 8 I of SMP 1 Jogoroto. The complete data is presented in the following table Ttest results Posttest English Reading skills. The posttest scores had a mean of 81,58 and Pretest scores had 64,53 the mean of the posttest scores is greater than the pretest scores $(81,58>58,6)$.

The test hypotheses regarding the effectiveness of using techniques Collaborative strategic reading (CSR) it is sought by looking at the effectiveness weights. This is to find out the effectiveness of using collaborative strategic reading toward students reading ability.

Collaborative strategic reading techniques according to Klinger and Vaughn (1998) aims to improve reading reading comprehension and enhance conceptual learning. Based on the results of the study showed that this technique can increase the motivation of students to be more active and enthsiastic in learning to read English, in addition this CSR technique is proven to be able to improve the achievment of English reading skills of 8th grade students of SMP 1 Jogoroto.

The steps for implementing Collaborative strategic reading (CSR) are:

1. The teacher divides students into groups.

2. The teacher divides the roles in each group member

3. The teacher divides reading material and worksheets in the form of learning logs on each group

4. The teacher asks students to read according to the stage of CSR. Namely preview, click and clunk, get the gist and wrap up

5. The teachers guides students in carrying out the CSR stages up to all stages exceeded.

6. The teacher ask each group to send one representative from the group to read the results of their learning log in front of the class

7. The teacher correct the lerning log of students if there are errors.

8. The teacher together with students make conclutions about the reading that has been they learned today.

The result of the pretest is not really good, it means that the students reading ability in SMPN 1 Jogoroto is low. The second try out of the pretest is good but the result not really satisfied. Fortunately after the researcher aplly the Collaborative strategic reading to students at $8 \mathrm{I}$ their scores of the post-test is increase. It means that the Collaborative strategic reading is improved the students reading ability in SMP 1 Jogoroto at 8I grade. The treatment was done 2 times with the limitation of 40 minutes at VIII I of SMP 1 
Jogoroto from march 14, 2020 to march 26, 2020. There was a pre-test before the Collaborative strategic reading treatment and post-test after the treatment.

The finding of this article was The use of collaborative strategic reading techniques in learning English reading skill effective in increasing students reading skill at 8I grade of SMP 1 Jogoroto. It is proved from the result of Pretest and posttest VIII I Grade of SMP 1 Jogoroto. Any significant difference in students reading skill before and after giving the Collaborative strategic reading treatment at 8I grade of SMP 1 Jogoroto. This is evidenced from the value of pretest and posttest in experimental class that after the students applied the collaborative strategic reading treatment their value in posttest better than the value in pretest. Using strategy is very urgent to decide all plans in learning process. Strategy can help the teacher in explaining or teaching the material in order to their students easier to understand what we learn in learning process (Sari, Y. A., \& Suhono, S. 2017; Suhono, S., \& Sari, Y. A. 2017). Other finding showed that more than 80 percent of the students gave vastly positive responses in relation to CSR classroom implementation. This approach not only helped them to develop their reading skills, but also produced positive outcomes in their social relationships and interactions in the classroom and gave significant main effect for proficiency level nor a significant interaction effect of reading intervention and proficiency (Gani et al., 2016: Babapour et al., 2019; Rosari \& Mujiyanto, 2016)). Teachers in CSR classrooms were also more likely to provide feedback to students and mainly motivated by the desire to highlight the significance of strategies in language teaching and study the way the new developments, in this area can facilitate and promote the process of reading comprehension (Boardman, A. G., et al., 2016; Nosratinia, \& Fateh, 2017).

\section{CONCLUSION}

Based on the results of the research and conclusions in discussion can be drawn as follow: There is significant difference in students reading skill before and after giving the Collaborative strategic reading treatment at 8I grade of SMP 1 Jogoroto. This is evidenced from the value of pretest and posttest in experimental class that after the students applied the collaborative strategic reading treatment their value in posttest better than the value in pretest. The use of collaborative strategic reading techniques in learning English reading skill effective in increasing students reading skill at 8I grade of SMP 1 Jogoroto. It is proved from the result of Pretest and posttest VIII I Grade of SMP 1 Jogoroto.

\section{REFERENCES}

Abidin, M. J. (2012). Collaborative Strategic Reading within cognitive and metacognitive strategies perspective. European Journal of Business and Management, 4, 61-69. Google Scholar

Alqarni, F. (2015). Collaborative strategic reading to enhance learners' reading comprehension in English as a foreign language. Academic Journal of Interdisciplinary Studies, 4(1), 161-161.Google Scholar

Arikunto, S. (2019). Dasar-dasar Evaluasi Pendidikan (edisi revisi). Google Scholar

Babapour, M., Ahangari, S., \& Ahour, T. (2019). The effect of shadow reading and collaborative strategic reading on EFL learners' reading comprehension across two proficiency levels. Innovation in Language Learning and Teaching, 13(4), 318-330. https://doi.org/10.1080/17501229.2018.1465059

Boardman, A. G., Vaughn, S., Buckley, P., Reutebuch, C., Roberts, G., \& Klingner, J. (2016). Collaborative strategic reading for students with learning disabilities in upper elementary classrooms. Exceptional Children, 82(4), 409-427. https://doi.org/10.1177\%2F0014402915625067

Boardman, A. G., Klingner, J. K., Buckley, P., Annamma, S., \& Lasser, C. J. (2015). The efficacy of Collaborative Strategic Reading in middle school science and social studies 
classes. Reading and Writing, 28(9), 1257-1283. https://doi.org/10.1007/s11145015-9570-3

Bremer, C. D. (2002). Collaborative Strategic Reading(CSR) Improving Secondary Students' Reading Comprehension Skills. Google Scholar

Finandar, F. (2012). Teaching Narrative Text Using CSR (Collaborative Strategic Reading) technique.

Gani, S. A., Yusuf, Y. Q., \& Susiani, R. (2016). Progressive outcomes of collaborative strategic reading to EFL learners. Kasetsart Journal of Social Sciences, 37(3), 144149. https://doi.org/10.1016/j.kjss.2016.08.004

Haikal, H. (2018). Interactive Metadiscourse And Interactional Metadiscourse Categories Of Students'international Program School Based On Gender. IJEE (Indonesian Journal of English Education), 5(1). https://doi.org/10.15408/ijee.v5i1.5505

Hasyim, U. A. A., \& Suhono, S. (2017). Restoring Moslem identity by integrating Islamic values in English speaking class. ATTARBIYAH: Journal of Islamic Culture and Education, 2(1), 1-27. https://doi.org/10.18326/attarbiyah.v2i1.1-27

Hoetomo. (2005). Kamus Lengkap Bahasa Indonesia. Mitra Belajar.

Jannah, S. N. (2020). Collaborative Strategic Reading (CSR) and Reading Comprehension across Reading Motivation. Language-Edu, 9(1). Google Scholar

Klingner, J. K. (1998). Using Collaborative Strategic Reading. Teaching Exceptional Children, 32-37. Google Scholar

Khonamri, F., \& Karimabadi, M. (2015). Collaborative strategic reading and critical reading ability of intermediate Iranian learners. Theory and Practice in Language Studies, 5(7), 1375-1382. http://dx.doi.org/10.17507/tpls.0507.09

Purnawan, L. N. (2019). The Influence of Using Collaborative Strategic Reading (CSR) Technique Onthe Students' Reading Skill in Drawing Conclusion at The Eleventh Grade of Smk Ganesha Sekampung in The Academic Year of 2019/2020 (Doctoral dissertation, IAIN Metro). Google Scholar

Rosari, L., \& Mujiyanto, Y. (2016). The effectiveness of know-want-learned and collaborative strategic reading strategies to teach reading comprehension to students with positive and negative attitudes. English Education Journal, 6(2), 3341. Google Scholar

Ross, M. J. (2020). Exploring the Effectiveness of Collaborative Strategic Reading for $\mathrm{K}-12$ Students through an Integrative Review (Doctoral dissertation, Regent University). Google Scholar

Nosratinia, M., \& Fateh, N. H. (2017). The comparative effect of collaborative strategic reading and content-based instruction on EFL learners' reading comprehension. International Journal of Applied Linguistics and English Literature, 6(6), 165-173. http://dx.doi.org/10.7575/aiac.ijalel.v.6n.6p.165

Saori, S. (2020). Influence of collaborative strategic reading (csr) in teaching reading comprehension. Jo-ELT (Journal of English Language Teaching) Fakultas Pendidikan Bahasa \& Seni Prodi Pendidikan Bahasa Inggris IKIP, 2(1), 48-57. Google Scholar

Sari, Y. A., Utama, F., \& Yawisah, U. (2019). Request and Politeness Strategy by Native Dayanese at OKU South Sumatra Indonesia. International Journal of Applied Linguistics and English Literature, 8(1), 230-235. Google Scholar

Sari, Y. A., \& Suhono, S. (2017). Applaying Transition Action Detail Strategy on Written Text of EFL Young Learners. Jurnal Iqra': Kajian Ilmu Pendidikan,2(1), 1-24. https://doi.org/10.25217/ji.v2i1.86

Sembiring, L. T. A. B. (2020). The impact of collaborative strategic reading and questioning the author on students'reading comprehension with different ability grouping and self-efficacy in universitas dehasen bengkulu (Doctoral dissertation, Universitas Negeri Semarang). Google Scholar 
Standish, L. G. (2005). The effects of collaborative strategic reading and direct instruction in persuasion on sixth-grade students' persuasive writing and attitudes (Doctoral dissertation). Google Scholar

Sugiyono. (2010). Metode penelitian pendidikan pendekatan kuantitatif, kualitatif, dan R\&D. Alfabeta. Google Scholar

Suhono, S., \& Sari, Y. A. (2017). Babbling stage construction of children's language acquisition on rural area lampung. JURNAL SMART, 3(2). Google Scholar

Suhono, S., \& Sari, Y. A. (2017). Retrofitting Javanese traditional games as Indonesia culture identity: Providing English vocabulary.Jurnal Iqra': Kajian Ilmu Pendidikan, 2(1), 213-226. https://doi.org/10.25217/ji.v2i1.123

Suhono, S. (2016). Surface strategy taxonomy on the efl students composition a study of error analysis. Jurnal Iqra': Kajian Ilmu Pendidikan, 1(2), 1-30. https://doi.org/10.25217/ji.v1i2.128

Tamah, S. (2000). The effect of in-class proofreading on students' composition. surabaya : Universitas Negeri Surabaya. Google Scholar

Vaughn, S., Klingner, J. K., Swanson, E. A., Boardman, A. G., Roberts, G., Mohammed, S. S., \& Stillman-Spisak, S. J. (2011). Efficacy of collaborative strategic reading with middle school students. American educational research journal,48(4), 938-964. https://doi.org/10.3102\%2F0002831211410305

Wu, J. Y., \& Peng, Y. C. (2017). The modality effect on reading literacy: Perspectives from students' online reading habits, cognitive and metacognitive strategies, and web navigation skills across regions. Interactive Learning Environments, 25(7), 859-876 https://doi.org/10.1080/10494820.2016.1224251

Copyright Holder :

(C) Anwar, A., (2020).

First Publication Right :

(C) Anglophile Journal

This article is under:

CC BY SA 